\title{
Spatiotemporal evolution characteristics of coordinated development of urbanization and ecological environment in eastern Russia
}

Nanchen Chu ( $\square$ chunanchen_1992@163.com )

Harbin Normal University https://orcid.org/0000-0002-2471-6340

Pingyu Zhang

Northeast Institute of Geography and Agroecology Chinese Academy of Sciences

Xiangli Wu

Harbin Normal University

\section{Research Article}

Keywords: urbanization, ecological environment, coupling coordinated degree, spatiotemporal pattern, eastern Russia

Posted Date: February 17th, 2022

DOI: https://doi.org/10.21203/rs.3.rs-1226576/v1

License: (c) (i) This work is licensed under a Creative Commons Attribution 4.0 International License. Read Full License 
1 Spatiotemporal evolution characteristics of coordinated development of 2 urbanization and ecological environment in eastern Russia

- Perspectives from the 3D global trend and 2D plane

\section{4 analysis}

5 Nanchen $\mathrm{Chu}^{1}$, Pingyu Zhang ${ }^{2}$, Xiangli $\mathrm{Wu}^{3}$

2 Northeast Institute of Geography and Agroecology, Chinese Academy Sciences, Changchun, Jilin 130102, China; College of Resources and Environment, University of Chinese Academy of Sciences, Beijing 100049, China. E-mail: zhangpy@iga.ac.cn 3 College of Geographical Sciences, Harbin Normal University, Harbin, Heilongjiang 150025, China. E-mail: jndxwxl@163.com

Abstract: Under the background of "the Belt and Road" and "the economic corridor of China, Mongolia and Russia" initiatives, it is of great significance to study the temporal and spatial evolution characteristics of the coordinated development between the urbanization and ecological environment in eastern Russia (the Siberian Federal District and the Far East Federal District). This paper studied the urbanization development level, eco-environment development level, and their coupling coordinated development degree during 2005-2018 in the eastern Russia from the perspectives of the 3D global trend and 2D plane analysis. First, combining with the Population-Economic-Sociology and Pressure-State-Response models, the paper constructed the index systems to evaluate the urbanization development level and eco-environment development level in eastern Russia. Second, based on the comprehensive weighting method of entropy weight and variation coefficient, this paper calculated the urbanization development level and eco-environment development level in eastern Russia. Third, the paper used the coupling coordination model to measure the coupling coordinated development degree of the urbanization development level and eco-environment development level in eastern Russia. Finally, the spatial differentiation of the urbanization development level, the eco-environment development level and their coupling coordinated development degree was performed respectively by the 3D global trend and 2D plane analysis using ArcGIS. The results are as following. First, the comprehensive urbanization development level of eastern Russia has increased from 2005 to 2018 , and the urbanization level of the economic aspect is the main factor that affects the urbanization development of eastern Russia. The comprehensive eco-environment development level of eastern Russia has decreased from 2005 to 2018, and the eco-environment pressure is the main factor that affects the eco-environment development of eastern Russia. The coupling coordination degree of the urbanization development and eco-environment development has increased from 2005 to 2018, but it is still in the uncoordinated stage. Second, from 2005 to 2018, the urbanization development level of the Siberian Federal District is higher than that of the Far East Federal District. The eco-environment development level of the Siberian Federal District is balanced to that of the Far East Federal District. The coupling coordination degree of the urbanization development and eco-environment development in the Siberian Federal District is higher than that in the Far East Federal District. Among the Siberian Federal District and the Far East Federal District, most of the federal subjects belong to the uncoordinated stage of the urbanization development and the eco-environment development. Third, the urbanization development level, the eco-environment development level, and their coupling coordinated development level are all spatially imbalanced in the eastern Russia, which show the "High West, Low East" and "High Center, Low North and South" spatial pattern from the perspectives of the 3D global trend and 2D plane analysis. The areas with high levels are concentrated in the Novosibirsk Region, Altay Territory, Kemerovo Region, Krasnoyarsk Territory, and Irkutsk Region. The areas with low ones are mostly in the Republic of Altay and Chukotka Autonomous Area. Finally, we suggest policies and strategies that can boost the growth and development of the urbanization and the eco-environment in the Sino-Russian 
projects, developing diversified tourism resources and products, accelerating the transformation of infrastructure, promoting the construction of the economic cooperation zone, and strengthening the protection and management of ecological environment, etc.

Key words: urbanization; ecological environment; coupling coordinated degree; spatiotemporal pattern; eastern Russia

\section{Introduction}

China proposed "the Belt and Road" initiative, including "the Silk Road Economic Belt" initiative and "the 21st-Century Maritime Silk Road" initiative in 2013. China issued the "Vision and Actions on Jointly Building Silk Road Economic Belt and 21st-Century Maritime Silk Road" in 2015, which meant that "the Belt and Road" initiative entered into a comprehensive promotion stage (Liu, 2015). In "the Belt and Road" initiative, relying on the important sea ports, the safe and efficient transportation channels will be built. And depending on the land transportation infrastructure, the six international economic corridors (new Eurasian Continental Bridge, ChinaMongolia- Russia, China- Central Asia- West Asia, China- Indochina Peninsula, China- Pakistan, BangladeshChina- India- Myanmar) will be constructed (Lu et al. 2017). And in the six international economic corridors, "China- Mongolia- Russia economic corridor" initiative will connect Russia’s "the Eurasian Economic Union" initiative and Mongolia's "Grassland Silk Road" initiative. Under the background of "the Belt and Road" and "the economic corridor of China, Mongolia and Russia" initiatives, the Sino-Russian relations were upgraded to a "comprehensive strategic partnership of coordination in the new era" in 2019. And the economic and trade relations have been improving between China and Russia in recent years. Northeast China and eastern Russia are the frontier areas of Sino-Russian economic and trade cooperation. The cross-border cooperation between Northeast China and eastern Russia could be helpful to the economic revitalization, economic security ensuring, European and American sanctions resisting, opening systems building and Asia Pacific integration participating in the future.

Eastern Russia is an important neighbor area of Northeast China. As the key areas of "the Belt and Road" and "China- Mongolia- Russia economic corridor" initiatives, eastern Russia and Northeast China have entered into a new stage of comprehensive opening-up and cooperation (Lu et al. 2017). The coordinated development of urbanization and ecological environment is not only the inevitable trend of global economic and social development, but also an important content of transnational economic cooperation between China and Russia. Researches on the urbanization and eco-environmental development in eastern Russia mainly focus on the analysis of urbanization development process, the discussion of urbanization development problems, and the research of different eco-environmental problems. (1) Analysis of urbanization development process. Shang (2015) analyzed that the urbanization of eastern Russia had experienced three important stages, including the early eastward expansion of the Principality of Moscow, the expansion of Russia in the Amur River Basin, and the 
climax of construction in the Tsarist Russian period. And relying on the rapid development of industrialization, the urbanization development of eastern Russia went through a urbanization road from west to east developing, from the center to around radiating, with military and administrative functions (Feng, 2014; Gао, 2014; Глушкова, 2004). Mishchuk (2013) reviewed the urbanization characteristics of immigrants in the Far East Federal District, including the reasons and characteristics of European immigrants settling in the Far East Federal District, the dynamics of forced and voluntary immigrants in the Far East Federal District, and the reasons for the formation of reverse migration flow in the Far East Federal District. (2) Discussion of urbanization development problems. The urbanization development in the Soviet Union was rapidly promoted by the industrialization development. After the disintegration of the Soviet Union, in the transition process from the planned economy to the market economy, the Russia's urbanization was in the stagnation because of the radical economic transformation and the regional serious crisis. And the urbanization development was characterized by the shrinking and extinction of small cities, the negative growth of urban and rural population, and the unstable development of urban system (Yu and Qiu, 2006). In the new era, Gao (2014), Li and Liu (2014) analyzed that the urban construction was developing slowly in the eastern Russia. There were a series of problems in the urbanization of eastern Russia, such as the slow development of urban agglomeration, the small number of mega cities, the single industrial structure of small and medium-sized cities, the urban imperfect hierarchical scale structure, the single urban functional structure, and the uneven distribution of urban spatial structure. Kuleshov and Seliverstov (2018) believed that the development and interaction between eastern Russia and Northeast China would solve the regional development imbalance and internal urbanization problems in eastern Russia. (3) Research of different eco-environmental problems. While developing mining, forest harvesting and high-consuming military enterprises, the ecological and environmental problems became more and more serious, such as the air pollution, water pollution, radioactive pollution, soil heavy metals, offshore pollution and forest resources loss in eastern Russia (Koshkin and Yevdoshenko, 2019; Zhou, 2008). Bityukova (2011) believed that the severity of urban air pollution mainly depended on the specialization degree of the industrial sectors in eastern Russia. Vasilenko (2015) believed that the depletion and quality deterioration of water resources were mainly affected by human water resources activities in the southern areas of western Siberian Federal District in eastern Russia. Zhuravel (2016) analyzed the impact of coal mining on the ecological environment, and he put forward the suggestions on sustainable and optimal operation efficiency in the southern Yakutia and Kuznetsk basins in eastern Russia. Based on the comprehensive index of human environmental intensity, Bityukova and Safronov (2015) rated the ecological environment status of cities in eastern Russia, such as air and water pollution, solid waste quantity, thermal pollution and radiation pollution. At present, most researches on the urbanization and ecological environment focus on unilateral analysis, and there 
are relatively few studies on the coordinated development of urbanization and ecological environment in eastern

105 Russia. Moreover, on the basis of long-time series of historical documents and historical data, most Chinese

106

scholars have carried out the qualitative research, judgment and discussion on urbanization and ecological environment in eastern Russia. Due to the data limitations, the quantitative and visual researches are obviously insufficient on the urbanization and ecological environment in eastern Russia. Especially in the past 10 years, the researches need to be continuously tracked and updated on the coordinated development of urbanization and ecological environment in eastern Russia.

Twenty-one federal subjects are distributed in the eastern Russia. There are great differences in physical geography, energy resources, geo-politics, economy and society among these different federal subjects. After the disintegration of the Soviet Union, Eastern Russia has experienced economic crises, and its urbanization and ecological environment are in an uncoordinated development condition. Eastern Russia is an important neighbor area of Northeast China. However, the urbanization and ecological environment development conditions of eastern Russia are not clear for China. This phenomenon has seriously affected the future cross-border cooperation in economy, trade, industry, transportation, communication, resources and environment between China and Russia. By studying the pattern of urbanization and ecological environment development in eastern Russia, it would be helpful to select cross-border cooperation nodes, building the cooperation channels and cooperation platforms between China and Russia. It also could be helpful to explore the complementary growth points of regional cooperation, so as to open a coordinated development pattern between China and Russia. Therefore, it is very important to study the coordinated development pattern of urbanization and ecological environment in eastern Russia. This paper studied the urbanization development level, eco-environment development level, and their coupling coordinated development degree during 2005-2018 in the eastern Russia from the perspectives of the $3 \mathrm{D}$ global trend and $2 \mathrm{D}$ plane analysis. Combining with the Population-Economic-Sociology and Pressure-State-Response models, the paper constructed the index systems to evaluate the urbanization development level and eco-environment development level in eastern Russia. Based on the comprehensive weighting method of entropy weight method and variation coefficient weight method, this paper calculated the urbanization development level and eco-environment development level in eastern Russia. The paper used the coupling coordination model to measure the coupling coordinated development degree of the urbanization development level and eco-environment development level in eastern Russia. And the spatial differentiation of the urbanization development level, the eco-environment development level and their coupling coordinated development degree was performed respectively by the $3 \mathrm{D}$ global trend and $2 \mathrm{D}$ plane analysis in ArcGIS. In the theory, this study can enrich the theoretical systems of urban geography and urban ecology. It can 
provide guidance and reference for similar related researches in other parts of the world, especially in China's adjacent areas. In the practice, this paper could help to clear the complementary points of bilateral cooperation between China and Russia. It can provide a scientific reference for regional development planning, economic optimization layout, energy and resource development and infrastructure construction in the adjacent areas of China and Russia in the future. It can provide suggestions for adjusting economic cooperation field and expanding the investment scale in the border cities of China and Russia in the future. It also can provide policy implications for determining the cooperation direction of border trade, transportation facilities, border tourism, border cooperation zone and ecological environment protection of China and Russia in the future.

\section{Materials and Method}

\subsection{Research area}

Eastern Russia contains the Siberian Federal District and the Far East Federal District (Figure 1). It is an important region connecting the Asia Pacific region and Europe, and it is also the frontier area of Russia's foreign economic cooperation. Siberian Federal District has ten federal subjects, including Republic of Altay, Republic of Tyva, Republic of Khakasia, Altay Territory, Krasnoyarsk Territory, Irkutsk Region, Kemerovo Region, Novosibirsk Region, Omsk Region and Tomsk Region (Figure 1). It has an administrative area of 4.36 million square kilometers, a population of 17.17 million, a population density of 3.9 people per square kilometer, a population urbanization rate of 74\%, and a regional GDP of 7.76 trillion rubles in 2018. Far East Federal District has eleven federal subjects, including Republic of Buryatia, Republic of Sakha(Yakutia), Zabaikalsk Territory, Kamchatka Territory, Primorsky Territory, Khabarovsk Territory, Amur Region, Magadan Region, Sakhalin Region, Jewish Autonomous Area and Chukotka Autonomous Area (Figure 1). It has an administrative area of 6.95 million square kilometers, a population of 8.19 million, a population density of 1.2 people per square kilometer, a population urbanization rate of $73 \%$, and a regional GDP of 3.88 trillion rubles in 2018. Although the urbanization rate in eastern Russia is high, the quality of urbanization is relatively low. Due to the financial resources lack for maintaining the normal operation of ecological environment infrastructures, the government is unable to modernize traditional environmental facilities. And the government is difficult to popularize the high-tech pollution prevention technologies, and some factories discharge large amounts of waste and toxic gases into the air. So the ecological and environmental problems have become increasingly serious in eastern Russia. 


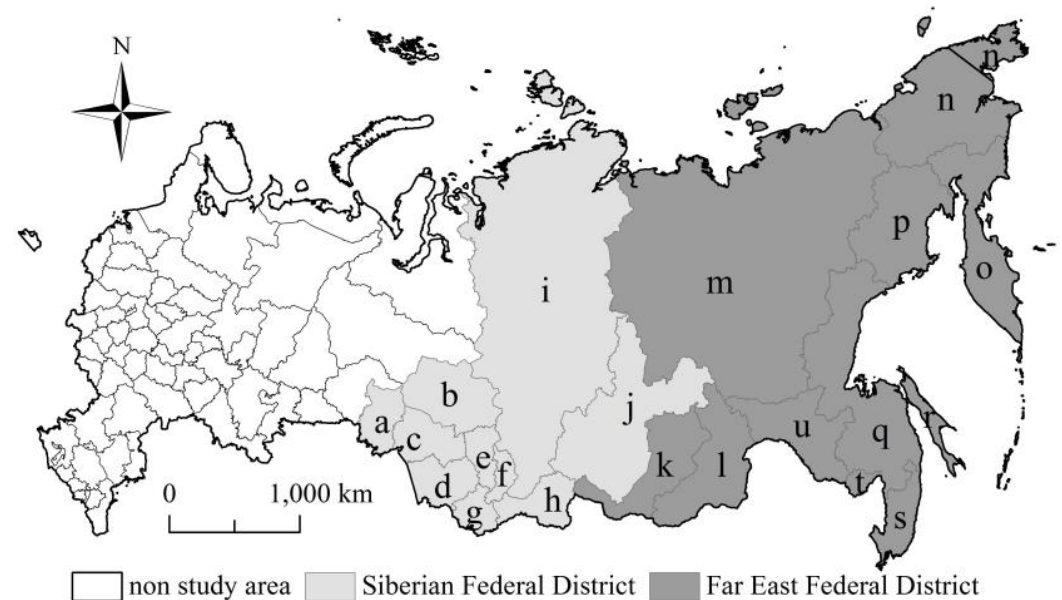

Figure 1. Sketch map of the study area.

Note: a Omsk Region. b Tomsk Region. c Novosibirsk Region. d Altay Territory. e Kemerovo Region. f Republic of Khakasia. g Republic of Altay. h Republic of Tyva. i Krasnoyarsk Territory. j Irkutsk Region. k Republic of Buryatia. 1 Zabaikalsk Territory. m Republic of Sakha(Yakutia). n Chukotka Autonomous Area. o Kamchatka Territory. p Magadan Region. q Khabarovsk Territory. $r$ Sakhalin Region. s Primorsky Territory. t Jewish Autonomous Area. u Amur Region.

\subsection{Research methods}

\subsubsection{Index systems of urbanization and eco-environment}

In the process of urbanization development, people are the subjects of behavior capacity and the ecological environment is the subjects of carrying capacity. The agglomeration of economic and industrial factors causes stress and squeeze effects on the ecological environment. At the same time, with the application and popularization of high and new technologies, the urban resource intensive utilization and environmental pollution control have been improving. With the improvement of ecological environment carrying capacity, cities are more suitable for human habitation. Therefore, the development of urbanization will bring "destruction" or "improvement" to the ecological environment. The ecological environment will also produce "containment" or "promotion" effect on urbanization development (Huang and Fang, 2003; Wang, 2011). According to the references (Chu et al. 2018; Fang, 2009; Li et al. 2012; Liang et al. 2019; Tan et al. 2015; Wang et al. 2014; Wang et al. 2015), in order to accurately evaluate the urbanization development level, ecological environment development level and their coordinated development degree in eastern Russia, this paper constructs the urbanization evaluation index system and ecological environment evaluation index system of eastern Russia following the principles of scientificity, representativeness, feasibility, comparability, systematicness and data availability, as shown in Table1.

Table 1. Evaluation systems of the urbanization and eco-environment in eastern Russia

\begin{tabular}{|c|c|c|c|c|c|c|}
\hline $\begin{array}{l}\text { First-Level } \\
\text { Indices }\end{array}$ & $\begin{array}{l}\text { Second-Level } \\
\text { Indices }\end{array}$ & $\begin{array}{l}\text { Third-Level } \\
\text { Indices, Unit }\end{array}$ & $\begin{array}{l}\text { Attrib } \\
\text {-ute }\end{array}$ & $\begin{array}{l}\text { Entropy } \\
\text { weight }\end{array}$ & $\begin{array}{l}\text { Variation } \\
\text { weight }\end{array}$ & $\begin{array}{l}\text { Compre- } \\
\text { hensive } \\
\text { weight }\end{array}$ \\
\hline Urbanization & Population & Proportion of non-agricultural population, $\%$ & + & 0.01 & 0.02 & 0.01 \\
\hline
\end{tabular}




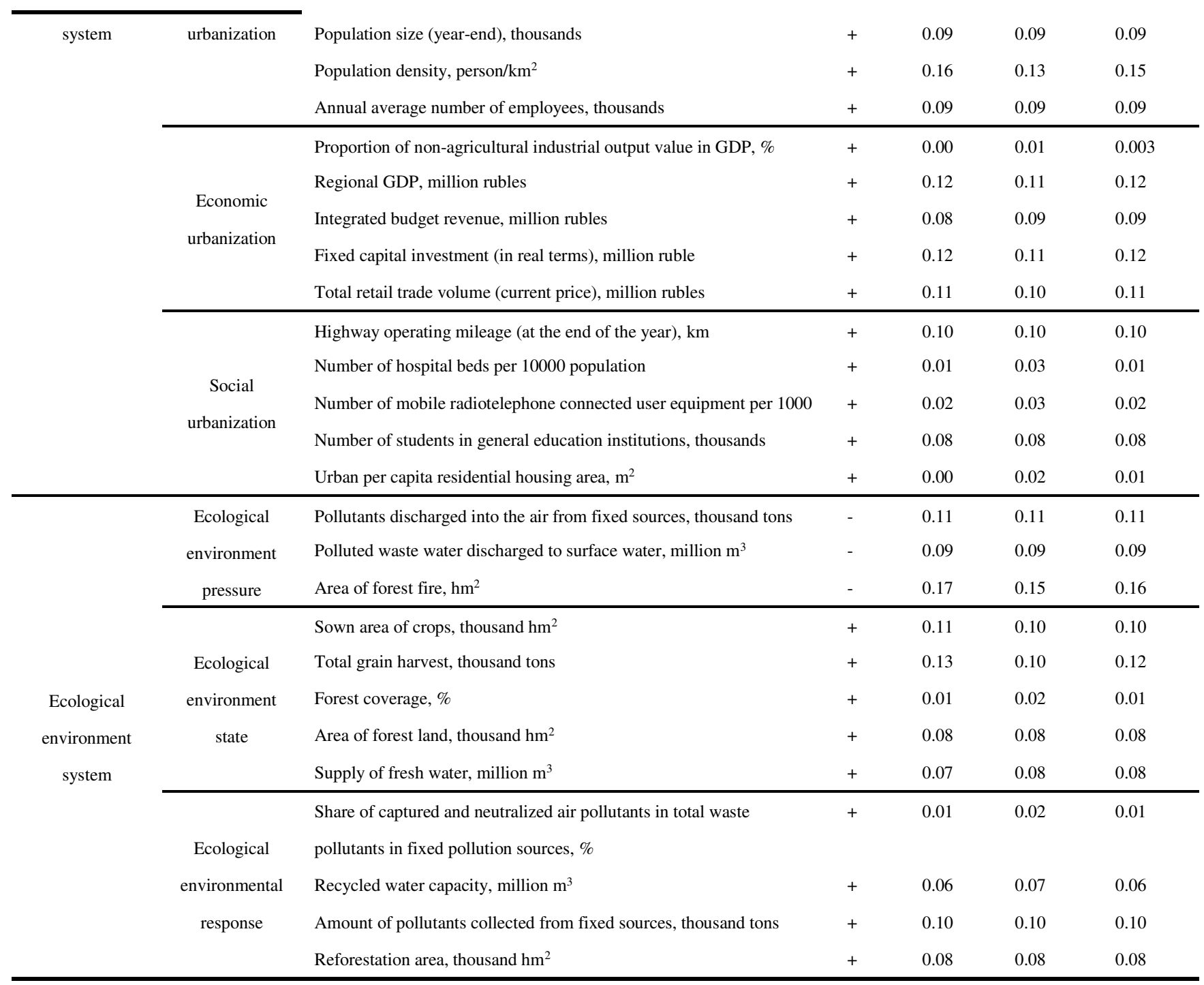

Urbanization is an economic and social development process in which non-agricultural industries gather in cities, rural population migrates to non-agricultural industries, the number of cities increases, the scale of cities expands, the mode of production and lifestyle of cities spread to rural areas, and the material and spiritual civilization of cities spread to rural areas (Chu et al. 2018). Based on the Population-Economic-Sociology (PES) model, this paper constructs the urbanization evaluation index system of eastern Russia (Chu et al. 2018; Fang, 2009; Huang and Fang, 2003; Li et al. 2012; Liang et al. 2019; Tan et al. 2015; Wang et al. 2015) (Table 1). And it measures the urbanization development levels with regard to the population urbanization, economic urbanization and social urbanization aspects in combination with fourteen indicators. Among them, population urbanization is the core content of urbanization development of eastern Russia. It is the process of rural population transferring to urban population. It is mostly measured by the proportion of urban population in the total population. It is the premise for the coordinated development of economic and social urbanization. Economic urbanization refers to the aggregation of economic factors and non-agricultural industries to cities, so as to promote economic 
development and enhance economic strength. It is mostly measured by the proportion of the output value of secondary and tertiary industries in GDP. It is the material basis for the development of population and social urbanization. Social urbanization is the improvement of social services, social infrastructure and life quality. On the premise of complete social infrastructure, population and economic urbanization could get reasonable development.

(2) Eco-environment evaluation system based on Pressure-State-Response (PSR) model

Ecological environment is a compound system of water resources, land resources and biological resources affecting human survival and sustainable development. Based on the Pressure-State-Response (PSR) model, this paper constructs the eco-environment evaluation index system of eastern Russia (Fang, 2009; Li et al. 2012; Liang et al. 2019; Tan et al. 2015; Wang et al. 2014; Wang et al. 2015) (Table 1). And it measures the eco-environment development levels with regard to the eco-environment pressure, eco-environment state and eco-environment response aspects in combination with twelve indicators. Among them, eco-environment pressure refers to the destruction, load and negative impact of human economic activities on the ecological environment. Eco-environment state is the health and safe condition of natural resources and ecosystem. Eco-environmental response refers to the feedback and resistance of the ecosystem in the face of human destruction, and it also refers to the measures taken by human beings when there are security problems in the ecosystem.

\subsubsection{Index preprocessing}

Based on the spatial scale of the eastern Russian federal subjects, this paper constructs the $21 * 14$ urbanization original data matrix and the $21 * 12$ ecological environment original data matrix during 2005-2018. Since the quantitative dimensions and units of 14 urbanization indicators and 12 eco-environment indicators of 21 federal subjects are quite different, it is necessary to standardize the original indicators and eliminate their quantitative dimensions. In this paper, the range standardization method is selected to remove the quantitative dimension of each index, so as to calculate the urbanization and ecological environment development levels of 21 federal subjects. The formula is as follows:

$$
X_{i j}=\frac{x_{i j}-x_{j \min }}{x_{j \max }-x_{j \min }}(\text { "+ " indicator }) \quad X_{i j}=\frac{x_{j \max }-x_{i j}}{x_{j \max }-x_{j \min }} \text { ("-." indicator) }
$$
where $x_{i j}$ is the original $j$ index value of the $i$ federal subject. $X_{i j}$ is the standardized $j$ index value of the $i$ federal subject. $x_{j \max }$ is the maximum value of the $j$ index. $x_{j \min }$ is the minimum value of the $j$ index.

\subsubsection{Index weight determination}

The methods for determining the weight of indicators include subjective weighting method and objective weighting method. Because the subjective weighting methods such as expert consultation are tendentious and the 
single objective weighting method has some errors, the two objective weighting methods of entropy weighting and coefficient variation weighting are selected to calculate the urbanization development level and the ecological environment development level of each federal subject. They could not only avoid the uncertainty of the subjective weighting method, but also could get rid of the defects of the single objective weighting method (Liu et al. 2017).

\section{(1) Entropy weighting method}

Entropy is used to measure the order degree or disorder degree of a system in classical physical thermodynamics. This paper draws lessons from the concept of entropy weight, characterizing the possible state of various indicators and their contribution to the urbanization system or ecological environment system. Generally speaking, the smaller the information entropy of the index, the smaller the chaos degree in the system, the higher the order degree in the system, the more effective information provided by the index, the greater the contribution of the index to the system, the more significant effect in the comprehensive index evaluation, and the higher the entropy weight of the index. The calculation process of entropy weighting method is as follows.

(1) Calculate the $j$ indicator proportion of $i$ federal subject $\left(p_{i j}\right): p_{i j}=x_{i j} / \sum_{i=1}^{m} x_{i j}$;

(2) Calculate the entropy of the $j$ indicator $\left(e_{j}\right): e_{j}=(-1 / \ln m) \sum_{i=1}^{m} p_{i j} \times \ln p_{i j}$;

(3) Calculate the entropy weight of the $j$ indicator $\left(w_{j}\right): w_{j}=\left(1-e_{j}\right) / \sum_{j=1}^{n}\left(1-e_{j}\right)$;

where $x_{i j}$ is the original $j$ index value of the $i$ federal subject. $m$ is the number of federal subjects. $n$ is the number of indicators.

(2) Coefficient variation weighting method

Coefficient variation is the proportion of the standard deviation to the average value. It considers the influence of the dispersion degree and average level of variable values. The greater the difference value of the same indicator in different federal subjects, the greater the weight of the indicator. And this indicator can better reflect the relative disparity in different federal subjects, and it has greater impact on the whole urbanization system or eco-environment system. The calculation process of coefficient variation weighting method is as follows.

(1)Calculate the mean value of the $j$ indicator $\left(\bar{x}_{j}\right)$ and the standard deviation of the $j$ indicator $\left(S_{j}\right)$.

(2) Calculate the coefficient variation of the $j$ indicator $\left(C V_{j}\right): C V_{j}=S_{j} / \bar{x}_{j}$; 
258 (3) Calculate the coefficient variation weight of the $j$ indicator $\left(u_{j}\right): u_{j}=C V_{j} / \sum_{j=1}^{n} C V_{j}$;

where $n$ is the number of indicators.

(3) Comprehensive weighting method

Two objective weights $w_{j}$ and $u_{j}$ of the indicator are calculated by entropy weighting method and coefficient variation weighting method respectively. The comprehensive weight value of the $j$ indicator $\left(p_{j}\right)$ is calculated by the comprehensive weight method to reduce the errors of the two objective weight methods. The calculation process of comprehensive weighting method is as follows.

$$
p_{j}=\sqrt{w_{j} \times u_{j}}
$$

where $p_{j}$ is the comprehensive weight of $j$ indicator. $w_{j}$ is the entropy weight of $j$ indicator. $u_{j}$ is the coefficient variation weight of $j$ indicator.

\subsubsection{Development level model}

Based on the development level model of linear weighting method, this paper calculates the population urbanization level, economic urbanization level, social urbanization level, comprehensive urbanization level, eco-environment pressure level, eco-environment state level, eco-environment response level, and comprehensive eco-environment level of 21 federal subjects in eastern Russia during 2005-2018. The calculation process of development level model is as follows.

$$
W_{i}=\sum_{j=1}^{n}\left(w_{j} \times X_{i j}\right) \quad U_{i}=\sum_{j=1}^{n}\left(u_{j} \times X_{i j}\right) \quad P_{i}=\sqrt{W_{i} \times U_{i}}
$$

where $W_{i}$ is the urbanization level or eco-environment level of the $i$ federal subject calculated by entropy weighting method. $U_{i}$ is the urbanization level or eco-environment level of the $i$ federal subject calculated by coefficient variation weighting method. $P_{i}$ is the comprehensive urbanization level or comprehensive eco-environment level of the $i$ federal subject.

\subsubsection{Coupling coordination model}

(1) Coupling degree model

There is a strong interaction between the urbanization development and the eco-environment development. Referring to the capacity coupling coefficient in the physics, a coupling model of urbanization and eco-environment suitable for eastern Russia is constructed. This model could characterize the "destruction" or "improvement" effect of the eco-environment in the process of urbanization development in eastern Russia, and the "containment" or "promotion" effect of the urbanization in the process of eco-environment development in eastern Russia. Through the stress, adaptation and interaction among the indicators within the urbanization system 
and the eco-environment system, the optimal sustainable development situation of urbanization and eco-environment will be achieved. The calculation process of coupling degree model is as follows.

$$
C=\left[\frac{P_{1} \times P_{2}}{\left(P_{1}+P_{2}\right)^{2}}\right]^{1 / 2}
$$

where $P_{1}$ is the urbanization development level of the $i$ federal subject. $P_{2}$ is the eco-environment development level of the $i$ federal subject. $C$ is the coupling degree of the urbanization development level and eco-environment development level of the $i$ federal subject.

(2) Coordinated development degree model

On the basis of coupling degree model, in order to truly study the interaction intensity, overall coordination situation between urbanization development and eco-environment development in eastern Russia, a coordinated development degree model of urbanization and eco-environment suitable for eastern Russia is constructed. The calculation process of coordinated development degree model is as follows.

$$
D=\sqrt{C \times T} \quad T=\alpha P_{1}+\beta P_{2}
$$

where $P_{1}$ is the urbanization development level of the $i$ federal subject. $P_{2}$ is the eco-environment development level of the $i$ federal subject. $D$ is the coordinated development degree of urbanization level and eco-environment level of $i$ federal subject, with the value of [0,1]. The closer the $D$ value is to 0 , the stronger the stress effect between urbanization and co-environment, the weaker the interaction effect between urbanization and eco-environment. The closer the $D$ value is to 1 , the stronger the coordinated effect between urbanization and eco-environment, the weaker the stress effect between urbanization and eco-environment. $T$ is the comprehensive coordination index of urbanization and eco-environment of $i$ federal subject. $\alpha, \beta$ respectively are the weight coefficients of urbanization and eco-environment. This paper believes that the urbanization and eco-environment are in the same important position, and $\alpha=\beta=0.5$ 。 According to the references (Liang et al. 2019; Tan et al. 2015; Wang et al. 2015), this paper classifies the coordinated development types of urbanization and eco-environment in eastern Russia into four categories and twelve subcategories (Table 2).

Table 2 Classification of coordinated development stages of urbanization and eco-environment

\begin{tabular}{llll}
\hline First-Level & Second-Level $($ Scope of $D)$ & Third-Level $\left(\right.$ Comparison of $\boldsymbol{P}_{\mathbf{1}}$ and $\left.\boldsymbol{P}_{2}\right)$ & Symbol \\
\hline & High-level coordinated development & Eco-environment lagging $\left(P_{1}-P_{2}>0.1\right)$ & I 1 \\
& $(0.8<D \leqslant 1.0)$ & Urbanization lagging $\left(P_{2}-P_{1}>0.1\right)$ & I 2 \\
Coordinated & & Urbanization and eco-environment balance $\left(0 \leqslant\left|P_{1}-P_{2}\right| \leqslant 0.1\right)$ & I 3 \\
development & Basic coordinated development & Urbanization lagging $\left(P_{2}-P_{1}>0.1\right)$ & II 1 \\
& $(0.5<D \leqslant 0.8)$ & Urbanization and eco-environment balance $\left(0 \leqslant\left|P_{1}-P_{2}\right| \leqslant 0.1\right)$ & II 3
\end{tabular}




\begin{tabular}{llll}
\hline & & & \\
& Basic uncoordinated development & Eco-environment lagging $\left(P_{1}-P_{2}>0.1\right)$ & III1 \\
Uncoordinated & $(0.3<D \leqslant 0.5)$ & Urbanization lagging $\left(P_{2}-P_{1}>0.1\right)$ & III2 \\
development & & Eco-environment lagging $\left(P_{1}-P_{2}>0.1\right)$ & III3 \\
& Serious uncoordinated development & Urbanization lagging $\left(P_{2}-P_{1}>0.1\right)$ & IV 1
\end{tabular}

\subsection{Data sources}

The data of urbanization indicators in this paper comes from the 《РЕГИОНЫ РОССИИ ОСНОВНЫЕ ХАРАКТЕРИСТИКИ СУБЪЕКТОВ РОССИЙСКОЙ ФЕДЕРАЦИИ СТАТИСТИЧЕСКИЙ СБОРНИК》 published on the official website of the Russian Bureau of Statistics "https://www.gks.ru" for the period 2006-2019. The data of eco-environment indicators in this paper comes from the 《РЕГИОНЫ РОССИИ СОЦИАЛЬНО-ЭКОНОМИЧЕСКИЕ ПОКАЗАТЕЛИ СТАТИСТИЧЕСКИЙ СБОРНИК》 published on the official website of the Russian Bureau of Statistics "https://www.gks.ru” for the period 2006-2019.

\section{Results of urbanization and eco-environment}

\subsection{Development level of urbanization and eco-environment}

\subsubsection{Urbanization}

From 2005 to 2018, in the urbanization system in eastern Russia, compared with the impact of population urbanization (with a comprehensive weight of 0.34) and social urbanization (with a comprehensive weight of 0.22), the impact of economic urbanization (with a comprehensive weight of 0.43 ) is the strongest. The population urbanization rate in eastern Russia has only increased from $68.37 \%$ in 2005 to $69.31 \%$ in 2018 , which is far lower than the average level of Russia. The population loss phenomenon is serious, and the quantity and quality level of labor force are relatively low in eastern Russia. However, the eastern Russia has a vast area and rich energy resources. It relies on the export of energy resources to obtain a large amount of foreign exchange income. The mining industry, metallurgy industry, electric power industry, automobile industry, machinery manufacturing industry, computer industry, atomic energy industry, consumer goods industry and synthetic material industry are numerous, becoming the main driving force for promoting the economic urbanization development in eastern Russia.

The population urbanization development level, economic urbanization development level, social urbanization development level, and comprehensive urbanization development level of eastern Russia are calculated based on the development level model of linear weighting method. From 2005 to 2018, the comprehensive urbanization development level of eastern Russia has shown the increasing trend (from 4.38 to 7.28). And the economic urbanization development level of eastern Russia has also shown the increasing trend, 
which is consistent with the comprehensive urbanization development trend. The population urbanization development level of eastern Russia has shown a stable change, and the social urbanization development level of eastern Russia has shown a slight increasing trend (Figure 2). The population urbanization development level, economic urbanization development level, social urbanization development level, and comprehensive urbanization development level of the Siberian Federal District are all higher than those of the Far East Federal District (Figure 3). The federal subjects with high urbanization development level are mainly distributed in the Novosibirsk Region, Krasnoyarsk Territory, Kemerovo Region, Altay Territory and Irkutsk Region. The federal subjects with low urbanization development level are mainly located in the Chukotka Autonomous Area, Jewish Autonomous Area, Magadan Region and Kamchatka Territory (Table 3) .
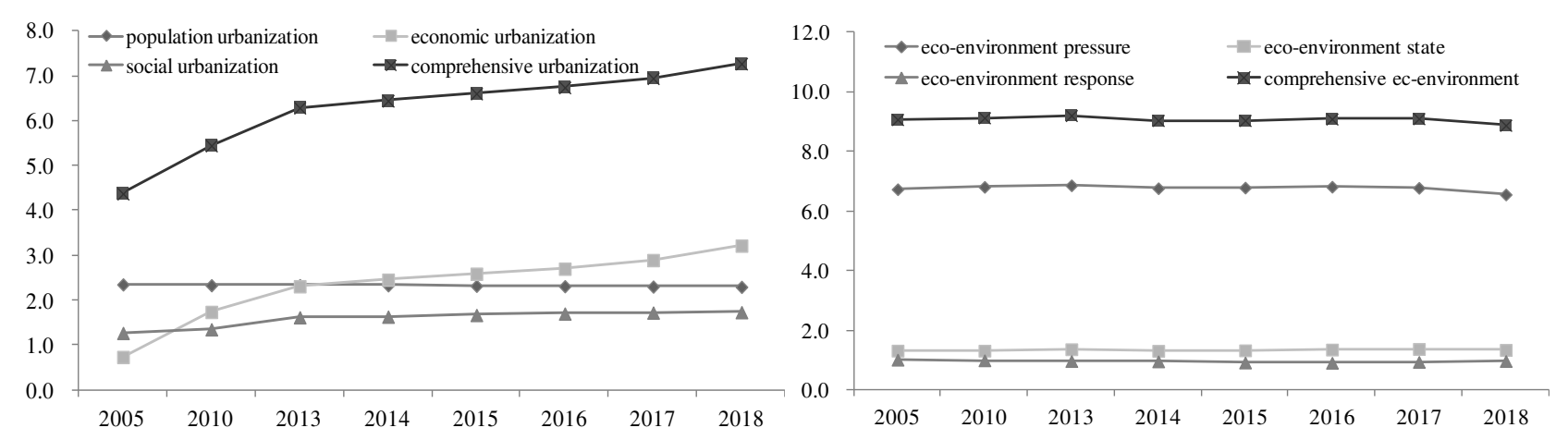

Figure 2. Urbanization and eco-environment development trend of eastern Russia from 2005 to 2018.

b. Eco-environment

Figure 3. Urbanization and eco-environment development trend of Siberian Federal District and Far East Federal

Table 3. Urbanization, eco-environment and their coupling coordination of each federal subject in eastern Russia in 2018

\begin{tabular}{|c|c|c|c|c|c|c|c|c|c|c|c|}
\hline \multirow[b]{2}{*}{ Federal subjects } & \multicolumn{4}{|c|}{ Urbanization } & \multicolumn{4}{|c|}{ Eco-environment } & \\
\hline & $\begin{array}{l}\text { Popu- } \\
\text { lation }\end{array}$ & $\begin{array}{l}\text { Econ- } \\
\text { omic }\end{array}$ & $\begin{array}{l}\text { Soc- } \\
\text { ial }\end{array}$ & $\begin{array}{l}\text { Compre- } \\
\text { hensive }\end{array}$ & $\begin{array}{l}\text { Pres- } \\
\text { sure }\end{array}$ & State & $\begin{array}{l}\text { Resp- } \\
\text { onse }\end{array}$ & $\begin{array}{l}\text { Compre- } \\
\text { hensive }\end{array}$ & $\begin{array}{l}\text { ing } \\
\text { degree }\end{array}$ & $\begin{array}{l}\text { develop- } \\
\text { ment } \\
\text { degree }\end{array}$ & $\begin{array}{l}\text { coordination } \\
\text { stage }\end{array}$ \\
\hline Republic of Altay & 0.02 & 0.02 & 0.03 & 0.07 & 0.36 & 0.01 & 0.00 & 0.37 & 0.37 & 0.28 & $\begin{array}{l}\text { Serious } \\
\text { uncoordinated }\end{array}$ \\
\hline
\end{tabular}




\begin{tabular}{|c|c|c|c|c|c|c|c|c|c|c|c|}
\hline Republic of Tyva & 0.03 & 0.02 & 0.04 & 0.09 & 0.35 & 0.01 & 0.01 & 0.38 & 0.39 & 0.30 & $\begin{array}{l}\text { Basic } \\
\text { uncoordinated }\end{array}$ \\
\hline Republic of Khakasia & 0.08 & 0.05 & 0.05 & 0.18 & 0.35 & 0.02 & 0.02 & 0.38 & 0.47 & 0.36 & $\begin{array}{l}\text { Basic } \\
\text { uncoordinated }\end{array}$ \\
\hline Altay Territory & 0.21 & 0.17 & 0.18 & 0.55 & 0.35 & 0.22 & 0.03 & 0.60 & 0.50 & 0.54 & $\begin{array}{l}\text { Basic } \\
\text { coordinated }\end{array}$ \\
\hline Krasnoyarsk Territory & 0.20 & 0.42 & 0.17 & 0.79 & 0.13 & 0.19 & 0.16 & 0.48 & 0.49 & 0.55 & $\begin{array}{l}\text { Basic } \\
\text { coordinated }\end{array}$ \\
\hline Irkutsk Region & 0.17 & 0.29 & 0.16 & 0.62 & 0.26 & 0.10 & 0.15 & 0.50 & 0.50 & 0.53 & $\begin{array}{l}\text { Basic } \\
\text { coordinated }\end{array}$ \\
\hline Kemerovo Region & 0.31 & 0.27 & 0.14 & 0.72 & 0.26 & 0.09 & 0.11 & 0.47 & 0.49 & 0.54 & $\begin{array}{l}\text { Basic } \\
\text { coordinated }\end{array}$ \\
\hline Novosibirsk Region & 0.26 & 0.28 & 0.15 & 0.69 & 0.34 & 0.12 & 0.03 & 0.49 & 0.49 & 0.54 & $\begin{array}{l}\text { Basic } \\
\text { coordinated }\end{array}$ \\
\hline Omsk Region & 0.19 & 0.17 & 0.11 & 0.47 & 0.33 & 0.14 & 0.06 & 0.53 & 0.50 & 0.50 & $\begin{array}{l}\text { Basic } \\
\text { coordinated }\end{array}$ \\
\hline Tomsk Region & 0.09 & 0.11 & 0.07 & 0.27 & 0.34 & 0.04 & 0.03 & 0.42 & 0.49 & 0.41 & $\begin{array}{l}\text { Basic } \\
\text { uncoordinated }\end{array}$ \\
\hline Republic of Buryatia & 0.07 & 0.19 & 0.07 & 0.33 & 0.35 & 0.04 & 0.04 & 0.42 & 0.50 & 0.43 & $\begin{array}{l}\text { Basic } \\
\text { uncoordinated }\end{array}$ \\
\hline Republic of Sakha (Yakutia) & 0.07 & 0.29 & 0.08 & 0.44 & 0.18 & 0.09 & 0.04 & 0.30 & 0.49 & 0.43 & $\begin{array}{l}\text { Basic } \\
\text { uncoordinated }\end{array}$ \\
\hline Zabaikalsk Territory & 0.08 & 0.10 & 0.09 & 0.27 & 0.33 & 0.04 & 0.04 & 0.40 & 0.49 & 0.40 & $\begin{array}{l}\text { Basic } \\
\text { uncoordinated }\end{array}$ \\
\hline Kamchatka Territory & 0.03 & 0.06 & 0.03 & 0.13 & 0.35 & 0.02 & 0.01 & 0.38 & 0.43 & 0.33 & $\begin{array}{l}\text { Basic } \\
\text { uncoordinated }\end{array}$ \\
\hline Primorsky Territory & 0.19 & 0.21 & 0.11 & 0.51 & 0.31 & 0.05 & 0.08 & 0.44 & 0.50 & 0.49 & $\begin{array}{l}\text { Basic } \\
\text { uncoordinated }\end{array}$ \\
\hline Khabarovsk Territory & 0.10 & 0.18 & 0.08 & 0.36 & 0.32 & 0.05 & 0.08 & 0.45 & 0.50 & 0.45 & $\begin{array}{l}\text { Basic } \\
\text { uncoordinated }\end{array}$ \\
\hline Amur Region & 0.07 & 0.14 & 0.07 & 0.27 & 0.25 & 0.06 & 0.04 & 0.35 & 0.50 & 0.39 & $\begin{array}{l}\text { Basic } \\
\text { uncoordinated }\end{array}$ \\
\hline Magadan Region & 0.02 & 0.04 & 0.03 & 0.10 & 0.35 & 0.02 & 0.01 & 0.39 & 0.40 & 0.31 & $\begin{array}{l}\text { Basic } \\
\text { uncoordinated }\end{array}$ \\
\hline Sakhalin Region & 0.07 & 0.19 & 0.04 & 0.30 & 0.35 & 0.02 & 0.01 & 0.38 & 0.50 & 0.41 & $\begin{array}{l}\text { Basic } \\
\text { uncoordinated }\end{array}$ \\
\hline Jewish Autonomous Area & 0.04 & 0.02 & 0.03 & 0.08 & 0.35 & 0.01 & 0.01 & 0.37 & 0.38 & 0.29 & $\begin{array}{l}\text { Serious } \\
\text { uncoordinated }\end{array}$ \\
\hline Chukotka Autonomous Area & 0.01 & 0.02 & 0.02 & 0.05 & 0.35 & 0.01 & 0.01 & 0.37 & 0.33 & 0.26 & $\begin{array}{l}\text { Serious } \\
\text { uncoordinated }\end{array}$ \\
\hline
\end{tabular}

In recent years, the urbanization level in eastern Russia has shown an increasing trend. In terms of population

358 urbanization, the government has introduced a preferential and assistance mechanism to stabilize the local 359 population. The government has also attracted foreign high-tech talents through the land donation, housing 
donation and special business methods, so as to vigorously promote the growth of the total population and non-agricultural labor force. In terms of economic urbanization, the corresponding industrial sectors with different advantages such as agriculture, forestry, fishery, energy, manufacturing, water conservancy, metallurgy, chemical industry, mining, construction, transportation and tourism are planned according to the different urban functional structures in different regions. For example, the government has built the wood deep-processing industrial clusters in the south areas of Far East Federal District, the fishery industrial clusters in the coastal areas of Far East Federal District, and tourism industrial clusters in Baikal Lake, Amur River and Primorsky Territory, so as to promote the aggregation of various economic factors to non-agricultural industries. In terms of social urbanization, the basic infrastructures such as transportation, energy and telecommunications have been planned. For example, the government will upgrade the Siberian Railway, integrate the roads of Far East Federal District into the Russian road network system, build the international aviation hubs such as Khabarovsk and Vladivostok, construct the oil and gas pipeline system between eastern Siberian Federal District and the Pacific Ocean, and build high-speed communication lines among the Primorsky Territory, China and Japan.

\subsubsection{Eco-environment}

From 2005 to 2018, in the eco-environment system in eastern Russia, compared with the impact of eco-environmental response (with a comprehensive weight of 0.26), the impact of eco-environment pressure (with a comprehensive weight of 0.38) and eco-environment state (with a comprehensive weight of 0.36) are stronger. In the process of urbanization development, the impact on the ecological environment in eastern Russia is mainly reflected in the eco-environment pressure, and the role of eco-environment protection needs to be further strengthened. There are a large number of traditional industrial cities in eastern Russia. Various minerals, oil and gas resources cause damage to vegetation, surface water and groundwater in the process of exploration, mining and transportation. Solid waste from the industrial production pollutes air, water and land. And these phenomena threaten the surrounding ecological environment, endanger the living environment, and reduce the environmental support and carrying capacity of urban development.

The eco-environment pressure level, eco-environment state level, eco-environmental response level, and comprehensive urbanization development level of eastern Russia are calculated based on the development level model of linear weighting method. From 2005 to 2018, the comprehensive eco-environment development level of eastern Russia has shown the slight decreasing trend. And the eco-environment pressure level, eco-environment state level, and eco-environmental response level have also shown the decreasing trend (Figure 2). The eco-environment pressure level, eco-environment state level, and eco-environmental response level, and comprehensive eco-environment development level of the Siberian Federal District are all balanced to those of the 
Far East Federal District (Figure 3). The federal subjects with high eco-environment development level are mainly distributed in the Altay Territory, Omsk Region, Novosibirsk Region, Irkutsk Region, Krasnoyarsk Territory and Kemerovo Region. The federal subjects with low eco-environment development level are mainly located in the Republic of Sakha(Yakutia), Amur Region, Chukotka Autonomous Area, Jewish Autonomous Area and Sakhalin Region (Table 3) .

The development of heavy industry in the Soviet Union left a series of environmental problems in eastern Russia. In recent years, in order to promote the urbanization development, while vigorously promoting the market economy in eastern Russia, the contradiction between natural resource development and ecological environment protection has become increasingly serious. The production activities of industrial enterprises in eastern Russia, such as fuel power industry, electric power industry, metallurgical industry, thermal power stations, and motor vehicles, emit a large amount of carbon dioxide, sulfur oxide, phenol, formaldehyde, ammonia, lead, suspended particles and other pollutants into the air. The continuous development of oil, gas, coal and other resources in eastern Russia has led to a long-term high-level of carbon density in the air. Agricultural and industrial production activities in eastern Russia, especially mining development and public utilities construction, discharge a large amount of pollutants into rivers. There are varying degrees of surface water pollution and groundwater pollution along Yenisei River, Amur River, Lena River and Obi river. The tributaries of these rivers, such as Ertis River, Tobor River, Tula River and Tommy River, are more seriously polluted. In addition, Krasnoyarsk Territory, Republic of Buryatia, Primorsky Territory, Sakhalin Region, and Kemerovo Region have high-risk land pollution of heavy metal salts. Kamchatka Territory has missile fuel with extremely aggressive and highly toxic substances. Primorsky Territory has decommissioned nuclear submarines to be destroyed. Some areas of Magadan Region have large amount of dangerous element of Radon. These radioactive and nuclear wastes diffuse under the action of air, causing serious threat and pollution to the ecological environment.

\subsection{Temporal and spatial pattern evolution of urbanization and eco-environment}

Based on the 3D perspective, the "global trend analysis" in ArcGIS was used to explore the change trend of urbanization development level and eco-environment development level in eastern Russia in the three dimensional space (Figure 4). The X-axis represents the east-west direction of the whole territory of eastern Russia (the arrow points to the East), and the Y-axis represents the north-south direction of the whole territory of eastern Russia (the arrow points to the North). The height of each vertical line of the Z-axis represents the urbanization development level or eco-environment development level of each federal subject. From 2005 to 2018, the urbanization development level and eco-environment development level in eastern Russia both show the spatial characteristics of "High West, Low East" in the east-west direction, which is reflected in the decreasing trend of the first-order 
function from west to east. From 2005 to 2018, the disparity of urbanization development level in eastern Russia shows an expanding trend in the north-south direction, which is reflected in the steady decreasing trend of the first-order function changing into a steep decreasing trend of the first-order function. The disparity of eco-environment development level in eastern Russia shows a shrinking trend in the north-south direction, which is reflected in the steep decreasing trend of the first-order function changing into the inverse U-shaped trend of second-order function.

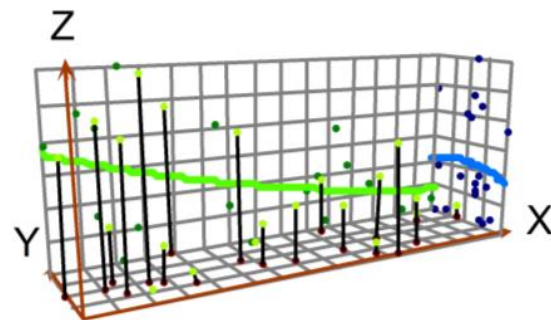

a. Urbanization (2005)

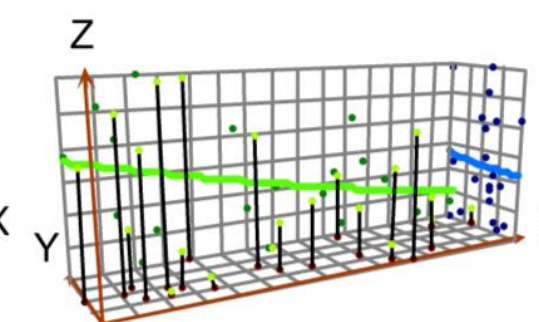

b. Urbanization (2010)

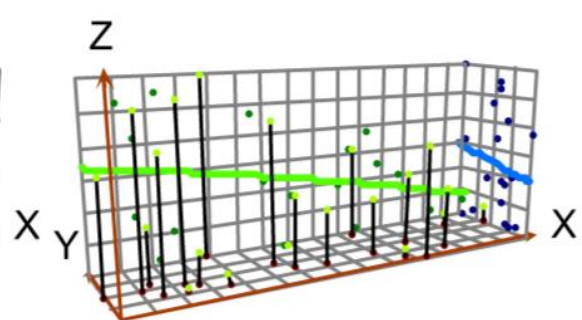

c. Urbanization (2018)

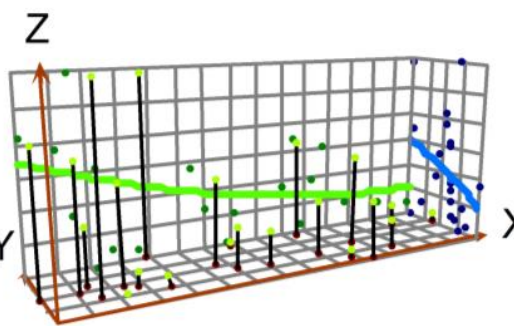

d. Eco-environment (2005)

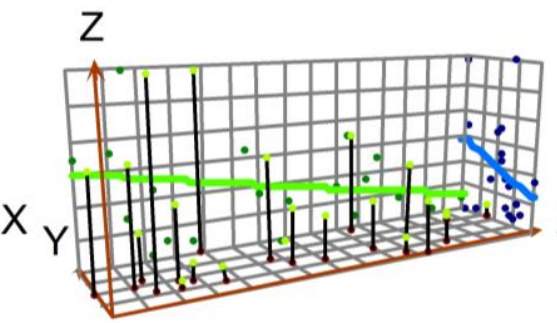

e. Eco-environment (2010)

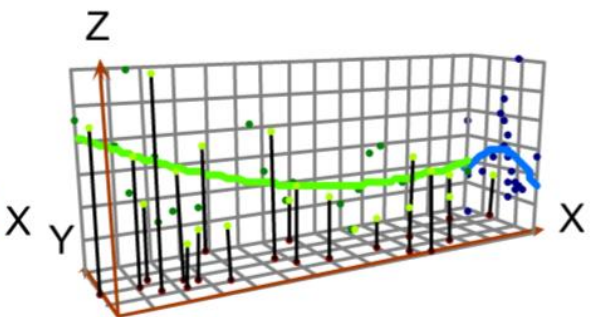

f. Eco-environment (2018)

Figure 4. Global trend changes of urbanization and eco-environment in eastern Russia from 2005 to 2018.

Based on the 2D perspective, the "spatial analysis function" in ArcGIS was used to explore the change trend of urbanization development level and eco-environment development level in eastern Russia in the two dimensional space (Figure 5). From 2005 to 2018, the urbanization development level of the federal subjects in eastern Russia shows the increasing trend, and the ecological environment development level of the federal subjects in eastern Russia shows the decreasing trend, which both characterize the "High West, Low East" pattern. With Irkutsk Region as the boundary, the urbanization development level and the eco-environment development level of Siberian Federal District are obviously stronger than those of the Far East Federal District. The areas with high urbanization development level and high eco-environment development level are mainly distributed in the series areas of Novosibirsk Region- Altay Territory- Kemerovo Region- Krasnoyarsk Territory- Irkutsk Region. The areas with low urbanization development level and low eco-environment development level are mainly located in the series areas of Republic of Altay- Republic of Tyva in the south of Siberian Federal District, and Kamchatka Territory- Chukotka Autonomous Area- Magadan Region in the northeast of Far East Federal District. 

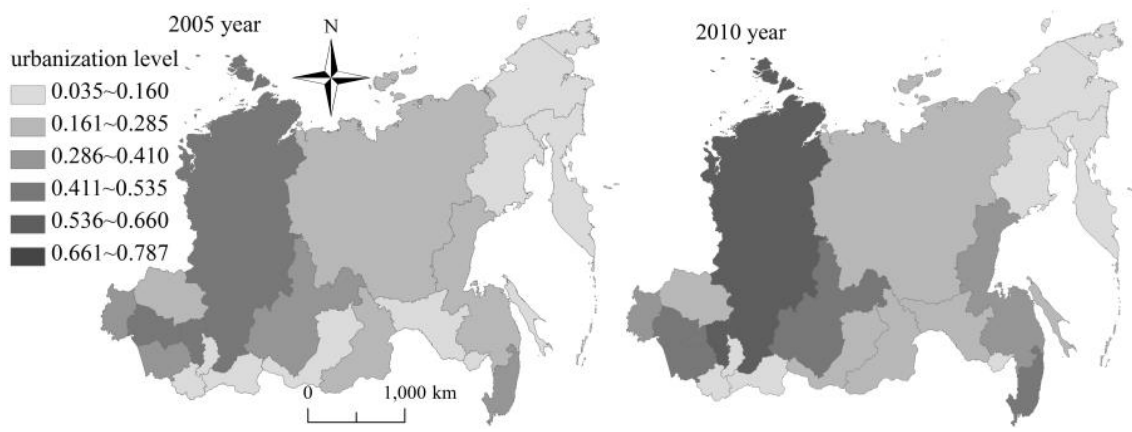

a. Urbanization (2005)

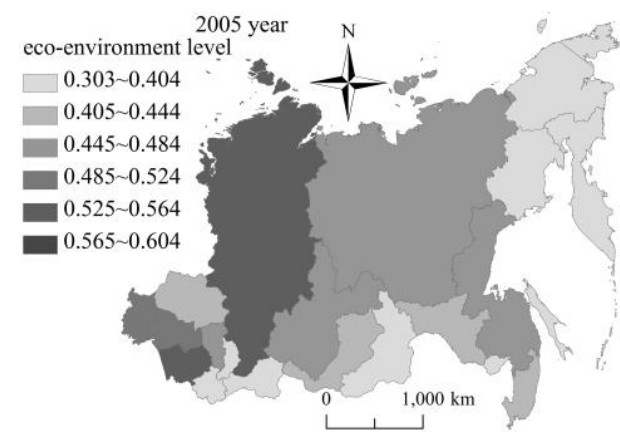

d. Eco-environment (2005) b. Urbanization (2010)

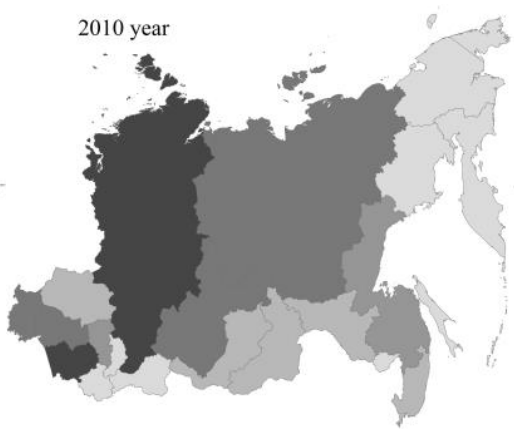

e. Eco-environment (2010)

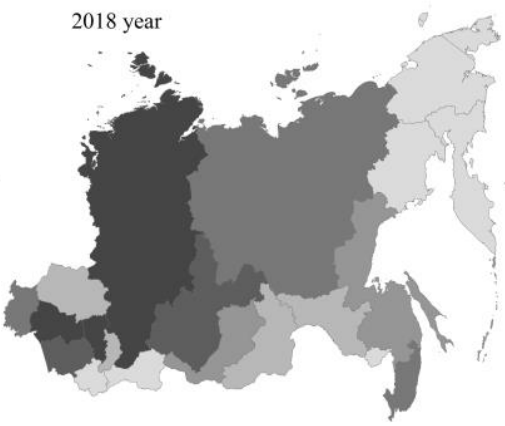

c. Urbanization (2018)

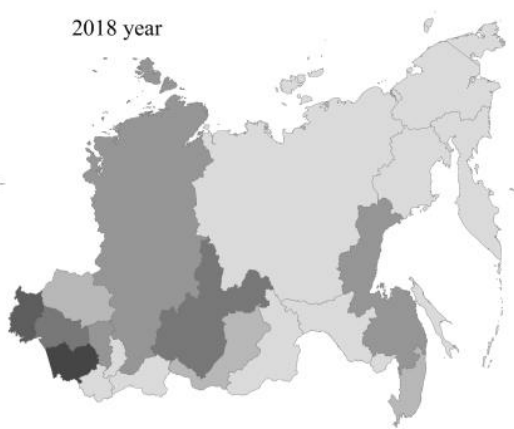

f. Eco-environment (2018)

Figure 5. Spatial pattern changes of urbanization and eco-environment in eastern Russia from 2005 to 2018.

The urbanization development level and eco-environment development level in Siberian Federal District are stronger than those in the Far East Federal District. Historically, Siberian Federal District was the Russia's economic and industrial center. It has dense population, strong immigrants attraction, high labor quality, strong economic strength, diversified industrial structure, outstanding foreign trade, strong scientific and technological innovation ability and dense transportation network. Its population, economic and social urbanization development levels are stronger than those of the Far East Federal District. The development purposes of the Far East Federal District is mainly for the territorial security and military defense. The opening of the Siberian Railway in 1916 meant the real development of the Far East Federal District. However, after the disintegration of the Soviet Union, the military industry shrank, which seriously damaged the economy of the Far East Federal District. In addition, Far East Federal District has unbalanced natural resources, lost human resources, underdeveloped economy, weak foreign cooperation, outdated technology and equipment, backward high-tech level, deep resource curse effect and imperfect social infrastructure (Ассекритов and Широбокова, 2011; Баранов and Скуфьина, 2005; Иванова, 2003). In particular, in recent years, the vulnerable areas with serious over exploitation of oil and natural gas lack modern pollution prevention and control facilities, aggravating their surface water, air and land pollution in the Far East Federal District. The forest coverage rate has decreased, and the eco-environment problems such as the shortage of water resources have become more serious in the Far East Federal District. In the future, under the background of meeting the shift of the world economic focus to the Asia Pacific region, under the influence of policies such as the 《Federal Special Outline for Economic and Social 
Development of the Far East Federal District and Zabaikalsk Territory before 2013》and 《Economic and Social Development Strategy of the Far East Federal District and Baikal Region before 2025》, the Far East Federal District has planned the southern urban agglomeration and island economic belt. The Far East Federal District has increased infrastructure construction in transportation and communications, energy resources and environmental protection, continuously consolidating its economic position in the Asia Pacific region. The Far East Federal District will become an important reserve economic security area of Siberian Federal District, and the urbanization and ecological environment disparity may be reduced between the Siberian Federal District and Far East Federal District.

\section{Results of coupling coordination between urbanization and eco-environment}

\subsection{Types of coupling coordination degree}

The coupling coordination model was used to measure the coupling coordinated development degree of the urbanization development level and eco-environment development level in eastern Russia. From 2005 to 2018, the coupling coordination development degree of urbanization and eco-environment in eastern Russia has showed an increasing trend, with $C$ value rising from 0.43 to $0.46, T$ value rising from 0.32 to 0.39 , and $D$ value rising from 0.37 to 0.42 . However, the overall situation of the urbanization and eco-environment in eastern Russia is still in the basic uncoordinated development, and the changes of its internal system is from the urbanization lagging to the urbanization and eco-environment balance. The urbanization and ecological environment of the Siberian Federal District and Far East Federal District are also in the basic uncoordinated development, with $C$ value: Siberian Federal District (0.47) > Far East Federal District (0.46), $T$ value Siberian Federal District $(0.45)>$ Far East Federal District (0.32), $D$ value: Siberian Federal District $(0.46)>$ Far East Federal District $\mathrm{t}(0.38)$. The coupling coordination development degree of Siberian Federal District is slightly stronger than that of the Far East Federal District. The changes of internal system is from the urbanization lagging to the urbanization and eco-environment balance in the Siberian Federal District. The internal system is still the urbanization lagging in the Far East Federal District. In 2018, the proportion of federal subjects with high-level coordination development, basic coordination development, basic uncoordinated development and serious uncoordinated development is $0.0 \%, 28.6 \%, 57.1 \%$ and $14.3 \%$ respectively. Most federal subjects are in the stage of basic uncoordinated development and the number of high-level coordination development is the least (Table 3 and Table 4). Krasnoyarsk Territory, Novosibirsk Region, Kemerovo Region, Altay Territory and Irkutsk Region have high coupling coordination development degree $(D>0.50)$, with the potential to achieve the high-level coordination development in the future. Other federal subjects are still in a state of uncoordinated development, with $D$ value less than 0.50 . 
Table 4. Coupling coordination stage of urbanization and eco-environment in each federal subject in eastern

\begin{tabular}{|c|c|c|c|c|c|c|c|c|}
\hline \multicolumn{9}{|c|}{ Russia } \\
\hline Federal subjects & 2005 & 2010 & 2013 & 2014 & 2015 & 2016 & 2017 & 2018 \\
\hline Republic of Altay & IV 2 & IV 2 & IV2 & IV 2 & IV 2 & IV 2 & IV2 & IV 2 \\
\hline Republic of Tyva & IV 2 & IV 2 & IV2 & IV 2 & IV 2 & IV 2 & IV 2 & III2 \\
\hline Republic of Khakasia & III2 & III2 & III2 & III2 & III2 & III2 & III2 & III2 \\
\hline Altay Territory & III2 & III2 & II 3 & II 3 & II 3 & II 3 & II 3 & II 3 \\
\hline Krasnoyarsk Territory & III2 & II 3 & II 1 & II 1 & II 1 & II 1 & II 1 & II 1 \\
\hline Irkutsk Region & III3 & III3 & II 3 & II 3 & II 3 & II 1 & II 1 & II 1 \\
\hline Kemerovo Region & III3 & II 1 & II 1 & II 1 & II 1 & II 1 & II 1 & II 1 \\
\hline Novosibirsk Region & III3 & II 3 & II 1 & II 1 & II 1 & II 1 & II 1 & II 1 \\
\hline Omsk Region & III2 & III2 & III3 & III3 & III3 & III3 & III3 & II 3 \\
\hline Tomsk Region & III2 & III2 & III2 & III2 & III2 & III2 & III2 & III2 \\
\hline Republic of Buryatia & III2 & III 2 & III2 & III2 & III2 & III2 & III2 & III3 \\
\hline Republic of Sakha (Yakutia) & III2 & III2 & III2 & III2 & III2 & III3 & III3 & III1 \\
\hline Zabaikalsk Territory & III2 & III2 & III2 & III2 & III2 & III2 & III2 & III2 \\
\hline Kamchatka Territory & IV 2 & III2 & III2 & III2 & III2 & III 2 & III2 & III2 \\
\hline Primorsky Territory & III2 & III3 & III3 & III3 & III3 & III3 & III3 & III3 \\
\hline Khabarovsk Territory & III2 & III2 & III2 & III2 & III2 & III2 & III2 & III3 \\
\hline Amur Region & III2 & III2 & III2 & III2 & III2 & III2 & III2 & III3 \\
\hline Magadan Region & IV 2 & IV 2 & IV2 & IV 2 & III2 & III2 & III2 & III2 \\
\hline Sakhalin Region & III2 & III2 & III2 & III3 & III3 & III3 & III3 & III3 \\
\hline Jewish Autonomous Area & IV 2 & IV 2 & IV2 & IV 2 & IV 2 & IV 2 & IV 2 & IV 2 \\
\hline Chukotka Autonomous Area & IV 2 & IV 2 & IV2 & IV 2 & IV 2 & IV2 & IV 2 & IV 2 \\
\hline
\end{tabular}

504

The coordinated development of urbanization and eco-environment is serious in eastern Russia. Under the situation of ecological environment decreasing, it is urgent to improve the "quality" of urbanization. According to Table 4, in 2005, eighteen federal subjects in eastern Russia belonged to the urbanization lagging type, and only three federal subjects belonged to the urbanization and eco-environment balance type. Urbanization lagging was the main type, and urbanization had a significant restrictive effect on the eco-environment in eastern Russia. In 2010, sixteen federal subjects in eastern Russia belonged to the urbanization lagging type, four federal subjects belonged to the urbanization and eco-environment balance type, and only one federal subject belonged to the eco-environment lagging type. Urbanization lagging was still the main type in eastern Russia. In 2018, nine federal subjects in eastern Russia belonged to the urbanization lagging type, seven federal subjects belonged to the urbanization and eco-environment balance type, and five federal subjects belonged to the eco-environment lagging type. The stress effect of urbanization on eco-environment has gradually decreasing in eastern Russia.

Although the urbanization development has brought harm to the eco-environment in eastern Russia, Russia has always been committed to the restoration and governance of the eco-environment. It has issued a series of 
laws, such as the 《Natural Environment Protection Law of the Russian Federation》, 《the National Ecological

519 Environment Law of the Russian Federation》, 《the Law of the Special Nature Protection Zone of the Russian

Federation》. It has also signed the 《Convention on International Trade in Endangered Species of Wild Animal and

521 Plant Species》, 《Convention on Biological Diversity》, 《Convention on Wetlands》, 《the United Nations

522 Convention on the Law of the Sea》 and other international agreements with other countries. Eastern Russia have

implemented various measures for eco-environment security protection in terms of improving the people's awareness of eco-environment protection, improving laws and regulations on eco-environment protection, strengthening the functions of corresponding administrative organs, establishing economic laws and regulations on environmental protection, implementing ecological insurance mechanism, and establishing special nature protection zones, so as to avoid the problems that the rapid urbanization development brings overload to the carrying capacity of resources and environment.

\subsection{Temporal and spatial pattern of coupling coordination degree}

The coordinated development degree of urbanization and eco-environment in eastern Russia from the 3D perspective shows the unbalanced pattern characteristics of "High West, Low East" and "High Center, Low South, Low North". The difference of coordinated development degree of urbanization and eco-environment in the east-west direction is greater than that in the north-south direction (Figure 6). From the 2D perspective, the coordinated development degree of urbanization and eco-environment in eastern Russia shows an increasing trend, which is similar to the pattern of urbanization and eco-environment, presenting the unbalanced differentiation characteristics of "High West, Low East". Compared with the Far East Federal District, the Siberian Federal District has larger coordinated development degree of urbanization and eco-environment. The federal subjects with high coordinated development degree of urbanization and eco-environment are mainly distributed in the serious areas of Omsk Region- Novosibirsk Region - Altay Territory- Kemerovo Region- Krasnoyarsk TerritoryIrkutsk Region. The federal subjects with low coordinated development degree of urbanization and eco-environment are mainly located in the Republic of Altay in the south of Siberian Federal District, and Chukotka Autonomous Area in the northeast of Far East Federal District (Figure 7) .

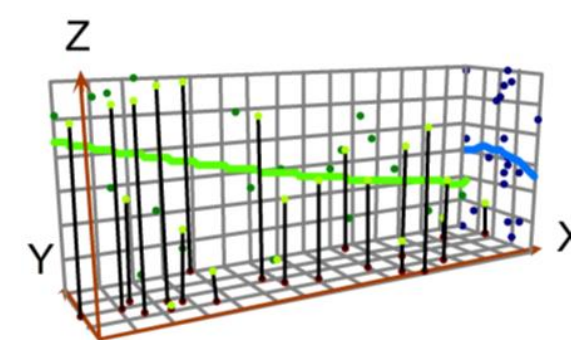

a. 2005

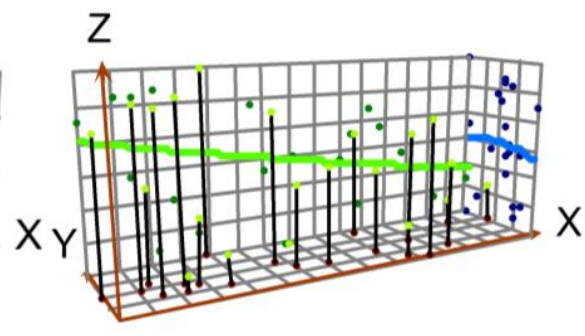

b. 2010

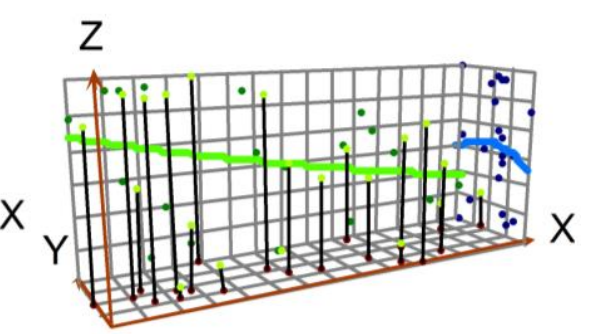

c. 2018

Figure 6. Global trend changes of coupling coordination degree between urbanization and eco-environment in 


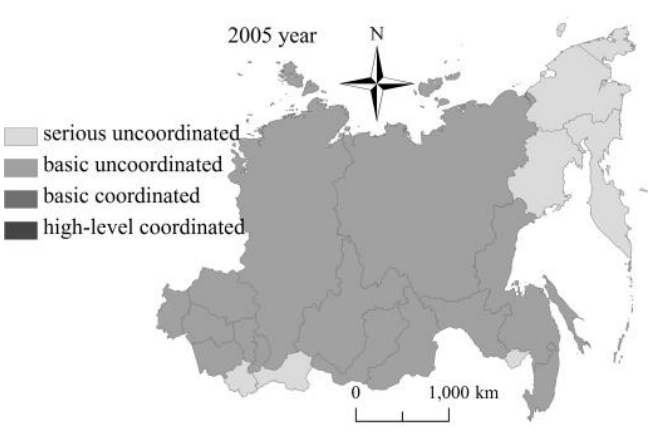

a. 2005

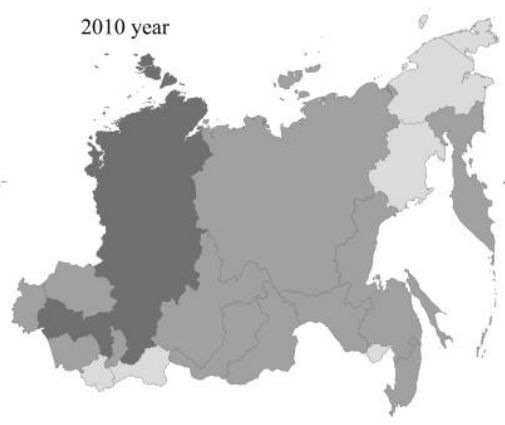

b. 2010

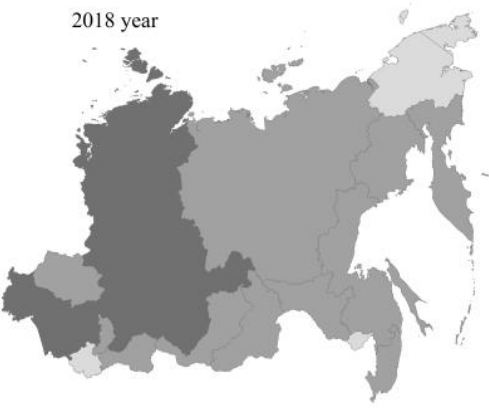

c. 2018

Figure 7. Spatial pattern changes of coupling coordination degree between urbanization and eco-environment in eastern Russia from 2005 to 2018

From 2005 to 2018, the coordinated development type of urbanization and eco-environment changes from the basic uncoordinated development type into the basic coordinated development type in Novosibirsk Region, Altay Territory, Kemerovo Region, Krasnoyarsk Territory and Irkutsk Region. And their internal system changes from the urbanization and eco-environment balance to the eco-environment lagging. These federal subjects have the leading levels of urbanization eco-environment in eastern Russia. As the economic development engine of the whole eastern Russia, relying on good regional advantages, rich resources and energy, diversified economic structure, dense transportation network, perfect logistics facilities and comprehensive security system, these federal subjects have developed into the economic zone along Siberian railway corridor. These federal subjects undertake the migration of economic factors in western Europe, becoming the gathering place of heavy industries such as machine manufacturing, energy processing, coal mining and metallurgy in Russia. All these have greatly promoted the urbanization development, but they also have a certain pressure on the eco-environment in these federal subjects. From 2005 to 2018, the coordinated development type of urbanization and eco-environment is still in the basic uncoordinated development type in Primorsky Territory, Khabarovsk Territory, Republic of Buryatia, Amur Region, Sakhalin Region, Republic of Sakha(Yakutia) and Omsk Region. And their internal system changes from the urbanization lagging to the urbanization and eco-environment balance. Primorsky Territory, Khabarovsk Territory, and Amur Region are the important economic growth areas in the Far East Federal District. They have the important function of Russia's integration into the Asia Pacific region, promoting the economic and trade cooperation in the Sino-Russian border areas. Republic of Sakha(Yakutia) and Sakhalin Region have great exploitation potential in energy resources. Excellent resource endowment is not only the value subject supporting the development of some resource-based cities, but also the source power of their economic urbanization development. Omsk Region is the connecting area of western Europe and eastern Asia in Russia. Republic of Buryatia is the border of China, Mongolia and Russia. Relying on location advantages, they have 
deepened the internal and external integration by creating superior internal and external markets, accelerating the investment attraction. From 2005 to 2018, the coordinated development type of urbanization and eco-environment is still in the basic uncoordinated development type in Zabaikalsk Territory, Tomsk Region and Republic of Khakasia. And their internal system is still in the urbanization lagging type. Attracted by the neighboring federal subjects with superior economy, these federal subjects have weak agricultural and light industrial production, small energy industry scale, insufficient scientific and technological innovation ability, weak economic diversified development, excessive external market dependence, outflow of capital and shortage of funds. Therefore, the urbanization development of these federal subjects lags behind the eco-environment. From 2005 to 2018, the coordinated development type of urbanization and eco-environment changes from the serious uncoordinated development type into the basic uncoordinated development type in Republic of Tyva, Kamchatka Territory and Magadan Region. The coordinated development type of urbanization and eco-environment is still in the serious uncoordinated development type in Republic of Altay, Jewish Autonomous Area and Chukotka Autonomous Area. And their internal system is still in the urbanization lagging type. These federal subjects are located in the marginal areas of eastern Russia. Limited by the severe climate conditions, low degree development, serious population outflow and poor transportation infrastructure, the resource and energy advantages and economic development potential of these federal subjects have not been fully utilized. Although the urbanization of these federal subjects is relatively slow, the ecological environment is maintained well.

\section{Discussion}

In recent years, the urbanization and eco-environment in eastern Russia are in an uncoordinated development stage. In the future, on the basis of solving the contradiction between natural resource development and ecological environment protection, eastern Russia should vigorously promote the improvement of urbanization quality. In addition, eastern Russia should coordinate the economic and social development strategies of twenty-one federal subjects, so as to achieve the goal of promoting the economic balanced development and the ecological environment protection. For example, on the basis of increasing regional financial support, optimizing regional infrastructure, protecting regional resources and environment, developing innovative economic model, optimizing industrial structure, and encouraging local governments functions, eastern Russia should create conditions for economic, social and ecological environment development, driving the development of marginal areas with advantageous areas to realize diversified development.

In the future, Siberian Federal District should build a modern economic metropolitan area with Novosibirsk Region as the core, radiating Altay Territory, Kemerovo Region, Krasnoyarsk Territory and Irkutsk Region. It could integrate production factors, implement innovation driven development strategy, promote economic 
transformation in resource-based areas, and vigorously develop modern service industry. At the same time, Siberian Federal District should develop the Arctic Development Zone on the basis of strengthening resource and energy exploration, restoring Arctic routes development, and protecting the original ecological environment. What's more, Siberian Federal District should develop the Northern Development Belt, focusing on automobile manufacturing, chemical industry, electric power and other industries. Siberian Federal District also should promote the Southern Development Belt, innovatively transforming its traditional economic sectors so as to develop industrial and economic cooperation zones with Asia Pacific and Central Asia.

In the future, on the basis of the common development of eco-environment protection and economic interests, the Far East Federal District should stabilize the local population, attracting foreign labor force. It also should focus on planning infrastructure such as energy, transportation and information, especially paying attention to the cooperation with Northeast Asia. In the northeast marginal areas Far East Federal District, it should get rid of the inherent anti-immigration and ethnic discrimination, improving the stable resettlement system for labor immigrants. It also should formulate economic and urban construction investment plans, restoring its economic activity in order to attract immigrants from other regions. In the south of Far East Federal District, it should develop the agricultural industrial complexes and tourism leisure clusters in Khabarovsk Territory and Primorsky Territory on the premise of protecting the eco-environment. It should use eco-environment protection raw materials to transform the industrial structure, developing its diversified advantages of innovative resources. It also should take advantage of the ports' advantages to enhance investment attraction, expanding production factors to other federal subject. In addition, it should deepen ecological and economic cooperation with northeast China, North Korea, South Korea and other neighboring countries, accelerating the planning and construction of transportation facilities synchronized with economic development.

In the future, eastern Russia also should vigorously implement the strategy of opening and developing, accelerating the urbanization and eco-environment development in the border areas, especially in the border areas between China and Russia. This has great significance in the realization of all-round and in-depth cooperation between China and Russia. Its future development and cooperation path includes six aspects. (1) Promote industrial division and cooperation. China and Russia should integrate the industrial production factors, implementing the innovation driven development strategy. They also should promote the economic transformation of resource-based areas, vigorously developing modern service industry. (2) Expand cooperation on energy projects. China and Russia should transform "loan for oil resources" into "joint investment and cooperative technology development". Chinese enterprises should settle in Russian border cities, extending the industrial chain of upstream exploration and production, midstream logistics and transportation, downstream sales and deep 
processing of oil and gas projects. (3) Create the tourism model of "internal connection and external expansion". China and Russia should develop diversified urban tourism products based on bilateral resource base and market demand, improving tourism projects such as vacation and self driving. (4) Accelerate the construction of infrastructure. China and Russia should speed up the construction of "Primorsky No. 1" and "Primorsky No. 2" international channels, developing the interconnection of Harbin-Dalian railway, Manzhouli-Harbin-Suifenhe railway, Siberian railway, and Baikal-Amur railway. And they also should comprehensively upgrade the software and hardware facilities of different border trade ports. (5) Construct the Free Trade Zone. On the basis of Harbin, Heihe and Suifenhe free trade zones, China and Russia should determine different leading industries in different cooperation parks, vigorously promoting the construction and development of bilateral cooperation parks. They also should implement the models, such as "two countries, one zone", "closed operation", "domestic and foreign customs", and "one zone and multiple parks". (6) Strengthen the protection and management of the eco-environment. China and Russia should establish protection and cooperation mechanism of tiger and leopard park. They should promote the ecological environment protection and governance of Khanka Lake. And They also should strengthen the ecological protection of Heilongjiang (Amur River) basin.

\section{Conclusions}

Since the implementation of Russia's "Eastward Migration Strategy", the urbanization of eastern Russia has been promoted rapidly, but the contradiction between natural resource development and ecological environment protection has become increasingly severe. Based on the comprehensive weighting method of entropy weight and variation coefficient weight, this paper studied the urbanization development level and the eco-environment development level in the eastern Russia during 2005-2018. And combined with the coupling coordination degree model, the paper studied the temporal and spatial evolution characteristics of the coordinated development of urbanization and eco-environment in eastern Russia during 2005-2018. The conclusions are as following.

From 2005 to 2018, the economic urbanization contributes the largest share to the urbanization system in eastern Russia. And the eco-environment pressure contributes the largest share to the eco-environment system in eastern Russia. The comprehensive urbanization development level of eastern Russia has shown the increasing trend. The economic urbanization development level of eastern Russia has also shown the increasing trend, the population urbanization development level of eastern Russia has shown a stable change, and the social urbanization development level of eastern Russia has shown a slight increasing trend. The comprehensive eco-environment development level of eastern Russia has shown the slight decreasing trend. And the eco-environment pressure level, eco-environment state level, and eco-environmental response level have also shown the decreasing trend. From 2005 to 2018, the coupling coordination development degree of urbanization 
and eco-environment in eastern Russia has showed an increasing trend. However, the overall situation of the urbanization and eco-environment in eastern Russia is still in the basic uncoordinated development, and the changes of its internal system is from the urbanization lagging to the urbanization and eco-environment balance. Under the situation of ecological environment decreasing, it is urgent to improve the "quality" of urbanization.

From 2005 to 2018, the population urbanization development level, economic urbanization development level, social urbanization development level, and comprehensive urbanization development level of the Siberian Federal District are all higher than those of the Far East Federal District. The eco-environment pressure level, eco-environment state level, and eco-environmental response level, and comprehensive eco-environment development level of the Siberian Federal District are all balanced to those of the Far East Federal District. The coupling coordination development degree of Siberian Federal District is slightly stronger than that of the Far East Federal District. The changes of internal system is from the urbanization lagging to the urbanization and eco-environment balance in the Siberian Federal District. The internal system is still the urbanization lagging in the Far East Federal District. Most federal subjects are in the stage of basic uncoordinated development and the number of high-level coordination development is the least. Krasnoyarsk Territory, Novosibirsk Region, Kemerovo Region, Altay Territory and Irkutsk Region have high coupling coordination development degree, with the potential to achieve the high-level coordination development in the future. Other federal subjects are still in a state of uncoordinated development.

Spatially, from the 3D perspective, the urbanization development level, the eco-environment development level and their coupling coordination development degree in eastern Russia all show the spatial characteristics of "High West, Low East" in the east-west direction and "High Center, Low South, Low North" in the north-south direction. And the difference of the urbanization development level, the eco-environment development level and their coupling coordination development degree in the east-west direction is greater than that in the north-south direction. From the 2D perspective, the urbanization development level, the eco-environment development level and their coupling coordination development degree in eastern Russia could characterize the "High West, Low East" pattern. The federal subjects with high urbanization development level, eco-environment development level and their coupling coordination development degree are mainly distributed in the serious areas of Novosibirsk Region - Altay Territory- Kemerovo Region- Krasnoyarsk Territory- Irkutsk Region. The federal subjects with low ones are mainly located in the Republic of Altay in the south of Siberian Federal District, and Chukotka Autonomous Area in the northeast of Far East Federal District.

From 2005 to 2018, the coordinated development type of urbanization and eco-environment changes from the basic uncoordinated development type into the basic coordinated development type in Novosibirsk Region, 
Altay Territory, Kemerovo Region, Krasnoyarsk Territory and Irkutsk Region. And their internal system changes from the urbanization and eco-environment balance to the eco-environment lagging. The coordinated development type of urbanization and eco-environment is still in the basic uncoordinated development type in Primorsky Territory, Khabarovsk Territory, Republic of Buryatia, Amur Region, Sakhalin Region, Republic of Sakha(Yakutia) and Omsk Region. And their internal system changes from the urbanization lagging to the urbanization and eco-environment balance. The coordinated development type of urbanization and eco-environment is still in the basic uncoordinated development type in Zabaikalsk Territory, Tomsk Region and Republic of Khakasia. The coordinated development type of urbanization and eco-environment changes from the serious uncoordinated development type into the basic uncoordinated development type in Republic of Tyva, Kamchatka Territory and Magadan Region. The coordinated development type of urbanization and eco-environment is still in the serious uncoordinated development type in Republic of Altay, Jewish Autonomous Area and Chukotka Autonomous Area. And their internal system is still in the urbanization lagging type.

Funding: This research was funded by National Natural Science Foundation of China (42101165, 42071162), China Postdoctoral Science Foundation (2021M693817), China Heilongjiang Philosophy and Social Sciences Research Planning Project (21JLC201) and China Heilongjiang Postdoctoral Science Foundation (LBH-Z21067).

\section{Data Availability Statement}

Some or all data, models or codes that support the findings of this study are available from the corresponding author upon reasonable request.

\section{Contributions}

Conceptualization, literature search, original draft and editing were done by Nanchen Chu. Pingyu Zhang reviewed the manuscript and Xiangli Wu provided the necessary resources to improve the manuscript.

\section{Corresponding author}

Correspondence to Nanchen Chu.

\section{Ethics declarations}

\section{Competing interests}

The authors declare no competing interests.

Ethics approval

Not applicable.

\section{Consent to participate}

Not applicable.

Consent to publish 
Not applicable.

\section{References}

Bityukova, V. R. Dynamics of atmospheric pollution by stationary sources. Regional Research of Russia, 2011, 1(4): 394-398.

Bityukova, V. R.; Safronov, S. G. Assessment of the ecological situation in Russia using the method of potential surfaces of human impact. Regional Research of Russia, 2015, 5(4): 367-377.

Chu, N. C.; Zhang, P. Y.; Li H.; Li, X. Measurement and spatial differentiation of urbanization development in the Siberian and Far East Federal Districts in Russia. Scientia Geographica Sinica, 2018, 38(7): 1069-1078.

Fang, C. L. Report on China's urbanization process and resources and environment protection. Science Press, 2009.

Feng, C. P. New characteristics of Russia's urbanization during the transitional period. Shanghai Urban Planning Review, 2014(5): 72-78.

Gao, J. X. Urbanization and urban development in Russia. Russian, East European \&Central Asian Studies, 2014(1): 38-45, 96.

Huang, J. C.; Fang, C. L. Analysis of coupling mechanism and rules between urbanization and eco-environment. Geographical Research, 2003, 22(2): 211-220.

Koshkin, E.; Yevdoshenko, S. I. Diversity and ecology of hawk moths of the genus Hemaris (Lepidoptera, Sphingidae) of the Russian Far East. Journal of Asia-Pacific Biodiversity, 2019, 12(4):614-626.

Kuleshov, V. V.; Seliverstov, V. E. Role of Siberia in Russia's spatial development and its positioning in the strategy for spatial development of the Russian Federation. Regional Research of Russia, 2018, 8(4): 345-353.

Li, S.; Liu, W. D. Spatial distribution of population in Russia and its evolution. Economic Geography, 2014, 34(2): $42-49$.

Li, Y. F.; Li, Y.; Zhou, Y.; Shi, Y. L.; Zhu, X. D. Investigation of a coupling model of coordination between urbanization and the environment. Journal of Environmental Management, 2012, 98(15): 127-133.

Liang, L. W.; Wang, Z. B.; Fang, C. L.; Sun, Z. Spatiotemporal differentiation and coordinated development pattern of urbanization and the ecological environment of the Beijing-Tianjin-Hebei urban agglomeration. Acta Ecologica Sinica, 2019, 39(4): 1212-1225.

Liu, C.; Deng, M.; Ran, C. H. Research on the coordinated development of agricultural modernization and new urbanization in Northeast China. China Population, Resources and Environment, 2017, 27(6): 155-162.

Liu, W. D. Scientific understanding of the Belt and Road Initiative of China and related research themes. Progress in Geography, 2015, 34(5): 538-544.

Lu, D. D.; Jiang, D.; Dong, S. C.; Wang, C. J.; Wang, J. E. Scientific understanding of "the belt, the road”. Science Press, 2017.

Mishchuk, S. N. Domestic and international migration in the Russian Far East in the mid-19th-early 21st century. Regional Research of Russia, 2013, 3(4):348-355.

Shang, Y. A review of the research on "the development of Siberian and Far East Federal Districts of Russia and the prospect of Sino-Russian cooperation”. International Data Information, 2015(10): 50-57, 19.

Tan, J. T.; Zhang, P. Y.; Li, J.; Liu, S. W. Spatial-temporal evolution characteristic of coordination between 

urbanization and eco-environment in Jilin Province, Northeast China. Chinese Journal of Applied Ecology, 2015, 26(12): 3827-3834.

Vasilenko, V. A. Water-economic problems in the southern part of western Siberia. Regional Research of Russia, 2015, 5(4): 378-383.

Wang, S. J.; Fang, C. L.; Wang, Y. Quantitative investigation of the interactive coupling relationship between urbanization and eco-environment. Acta Ecologica Sinica, 2015, 35(7): 2244-2254.

Wang, S. J.; Ma, H.; Zhao, Y. B. Exploring the relationship between urbanization and the eco-environment: A case study of Beijing-Tianjin-Hebei region. Ecological Indicators, 2014, 45: 171-183.

Wang, X. F. Evolvement of urbanization patterns in developed countries and its application to China. Areal Research and Development, 2011, 30(4): 54-60.

Yu, L.; Qiu, X. P. Research on the process of urbanization in Russia since the transition. Russian Studies, 2006(2): 52-57.

Zhou, H. T. On the environmental problems in the Far East of Russia. Siberian Studies, 2008(4): 56-58.

Zhuravel, N. M. Systematic evaluation of environmental and economic effectiveness of the best available technologies: regional dimension. Regional Research of Russia, 2016, 6(2):193-202.

Ассекритов, С.; Широбокова, В. Межбюджетные отношенения: проблемы и подходы к их решению. Экономист, 2001(1): 67-70.

Баранов, С.; Скуфьина, Т. Анализ межрегиональной дифференциации и построение рейтингов субъектов российской федерфциии. Экономист, 2005(8): 20-24.

Глушкова, В. Г. Введение в экономическую географию и регионаьную экономику. России, 2004: 161.

Иванова, В. Финансово-кредитные организации в системе регионального управления социальноэкономическим развитием. Экономист, 2003(7): 27-33. 